\title{
ANALISIS KOMPARATIF ABNORMAL RETURN DAN TRADING VOLUME ACTIVITY EMITEN SEKTOR MINING BERDASARKAN PENGUMUMAN KASUS PASIEN COVID-19 PERTAMA DI INDONESIA
}

\author{
Lailatul Akhadiyah \\ Universitas Negeri Surabaya \\ lailatul.17080574042@mhs.unesa.ac.id \\ Yuyun Isbanah \\ Universitas Negeri Surabaya \\ yuyunisbanah@unesa.ac.id
}

\begin{abstract}
On March 2nd 2020, the first case of Covid-19 was found in Indonesia. The purpose of this research is to analyze the reaction of the Indonesian capital market to the first case of Covid-19 using average abnormal return (AAR), cumulative abnormal return (CAR), and trading volume activity (TVA) before and after the event. The observation began seven days before and seven days after that event. The population of this research uses the data of mining sector companies listed in February and March 2020 on the BEI. The sampling technique used is purposive sampling with a total of 41 mining companies. This study uses quantitative research and the comparative method - the research testing by Wilcoxon Signes Rank Test. The result showed no differences in AAR, CAR, and TVA of mining sectors between before and after the announcement of the first cases of Covid-19. Investors are expected to be more careful in making investment decisions because this pandemic has occurred for a long time and around the world.
\end{abstract}

Keywords: AAR; CAR; covid-19; event study; TVA.

\section{PENDAHULUAN}

Menurut Ahyaruddin et al. (2017), kegiatan investasi dipengaruhi oleh informasi yang tersedia melalui sebuah peristiwa yang terjadi di masyarakat, sehingga dalam upaya pengambilan keputusan investasi, investor harus mengumpulkan informasi sebanyak mungkin agar kegiatan investasi yang dilakukan dapat mendatangkan keuntungan bagi para investor.

Menurut Luhur (2010), beberapa aktivitas fundamental yang dapat memengaruhi pasar modal. Adapun aktivitas tersebut bisa bersumber dari kegiatan ekonomi ataupun non ekonomi. Fenomena ekonomi yang dimaksud di antaranya fluktuasi value kurs, kebijakan fiscal, kebijakan moneter, tingkat interest rate, policy of devidend, decision of stategy dari perusahaan ataupun saat RUPS. Fenomena nonekonomi yang dapat memengaruhi pasar modal antara lain kondisi environment, isu Hak Asasi Manusia (HAM), aksi terorisme, demonstration, juga fenomena politik yang sangat rawan terhadap capital market.

Sambuari et al. (2020) mengatakan jika sensitifitas reaksi pasar modal terhadap sebuah kondisi yang terjadi berbanding lurus dengan besarnya peran pasar modal terhadap perekonomian. Hal ini dikarenakan trading volume activity dan harga saham dipengaruhi oleh kondisi atau peristiwa yang terjadi di suatu negara karena fenomena itu disinyalir mempunyai muatan berita untuk para investor. Sejak 17 November 2019 kasus pertama pasien Covid-19 ditemukan hingga saat ini sedang berlangsung pandemi Covid-19 yang menyebar pelosok negara-negara di dunia, WHO berperan guna mengomunikasikan risiko wabah ke publik sehingga akan membentuk sentimen investor terhadap wabah ini. Sentimen investor dapat memengaruhi pasar modal secara signifikan. Apabila investor memiliki sentimen tren pasar akan positif, investor akan cenderung optimis, dan sebaliknya jika sentimen investor tren pasar akan turun, investor cenderung menunggu untuk memasuki pasar (Liu et al., 2020). 
Lailatul Akhadiyah \& Yuyun Isbanah. Analisis Komparatif Abnormal Return dan Trading Volume Activity Emiten Sektor Mining Berdasarkan Pengumuman Kasus Pasien Covid-19 Pertama di Indonesia

Covid-19 mulai melanda Indonesia sejak Maret 2020 (CNNIndonesia, 2020). Hal ini merupakan bad news sehingga para investor melakukan aksi panic selling. Akibatnya harga saham terperosok pada Maret 2020 (Bisnis.com, 2020).

Menurut Khoiriah et al. (2020), pandemi Covid-19 menyebabkan kerugian ekonomi yang tercermin dalam fluktuasi harga saham. Penyebaran Covid-19 dikatakan sangat cepat dan berdampak bagi perekonoman Indonesia sehingga pemerintah Indonesia menerapkan berbagai kebijakan untuk menghambat penyebarannya, mulai dari aturan Pembatasan Sosial Berskala Besar (PSBB), anjuran untuk tetap di rumah, dan aturan jaga jarak (Kemenkes, 2020).

Kondisi lingkungan yang disinyalir menjadi bad news bagi para investor yaitu adanya pandemi Covid19. Sesudah adanya pemberitaan kasus Covid-19 awal kali di Indonesia, pasar modal langsung bereaksi. Nilai tukar semakin menurun. IHSG yang awalnya stabil juga mengalami penurunan yang cukup signifikan setelah adanya kasus pasien Covid-19 di Indonesia. IHSG pada Maret 2020 mengalami penurunan hingga $-4,44 \%$ (Idxchannel.com, 2020).

Pandemi Covid-19 telah memperburuk perekonomian. Dilihat dari indeks sektoral bulan FebruariMaret 2020, sektor mining merupakan sektor yang paling kuat dalam menghadapi dampak pandemic Covid-19 karena investor memiliki keyakinan bahwa sektor mining akan cepat pulih dalam kurun waktu singkat (Kompas.com, 2020). Penurunan indeks sektoral dapat diamati di Gambar 1.

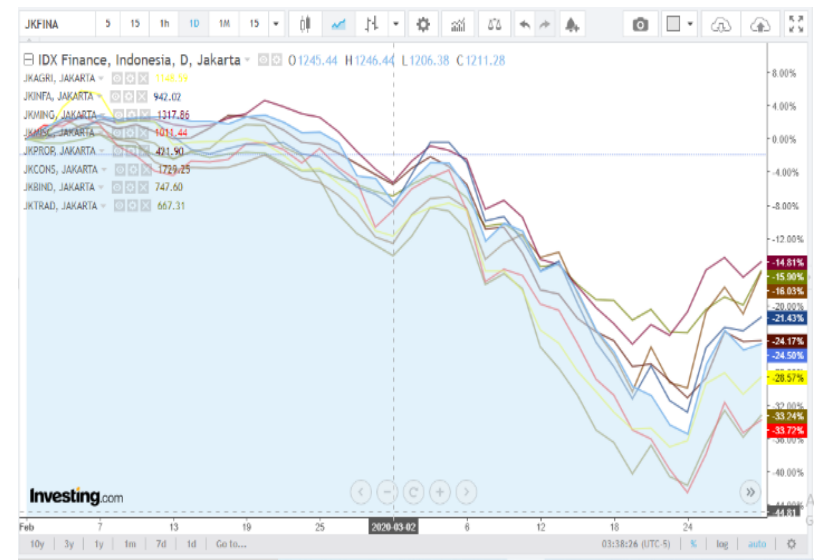

Sumber: Investing.com (2020)

\section{Gambar 1. GRAFIK INDEKS SAHAM SEKTORAL BULAN FEBRUARI-MARET 2020}

Gambar 1 menunjukkan bahwa sektor mining menjadi sektor terkuat daripada sektor-sektor lainnya karena memiliki tren penurunan yang tyhzidak terlalu signifikan, sehingga hal tersebut mengindikasikan bahwa return dari sektor mining tidak terjun bebas. Salah satu penggerak roda perekonomian saat pandemi bersumber dari sektor mining. Sektor mining memberikan kontribusi positif yang tercermin dari nilai ekspor yang positif (Sindonews.com, 2020).

Dilihat dari Gambar 1, secara keseluruhan grafik tersebut juga mengindikasikan bahwa IHSG juga mengalami penurunan (bearish). Terjadinya tren penurunan IHSG disebabkan adanya suatu peristiwa yang mempunyai suatu muatan berita untuk para investor, baik berita yang sifatnya buruk ( $\mathrm{bad}$ news) atau informasi yang baik bagi investor (good news). Kondisi perusahaan dapat dilihat dari harga sahamnya, sebab saat permintaan saham tinggi, akibatnya harga saham pun terstimulus dan sebaliknya. Sehingga situasi perusahaan pun dapat diamati melalui besarnya ju11al-beli saham yang diperjualbelikan, karena hal ini mencerminkan seberapa besar minat investor untuk memiliki saham tersebut (Nurmasari, 2020).

Menurut Hartono (2017:644), reaksi pasar dapat dicerminkan melalui perolehan abnormal return yang mengindikasikan pasar terstimulus saat berita yang bermuatan dengan suatu fenomena sehingga dapat merubah penilaian investor terhadap nilai perusahaan. Menguji average abnormal return (AAR) saham 
dipergunakan untuk mengetahui abnormal return secara cross-section di setiap periode peristiwa, kemudian menghitung AR kumulatif dilakukan untuk membandingkan signifikansi antara sebelum dan setelah adanya peristiwa. Menurut Susanti (2015), sebuah fenomena bermuatan berita yang positif dapat mendatangkan return yang positif dan sebaliknya suatu peristiwa tersebut sifatnya negatif ( $b a d$ news) memuncul return yang negatif. Menurut Alexander \& Kadafi (2018), trading volume activity bisa dipakai guna mengamati respon pasar kepada sebuah peristiwa, hal ini karena semakin tinggi TVA maka terdapat kemungkinan suatu saham sangat diminati oleh investor sehingga mudah untuk diperjual belikan.

Ekspektasi investor tercermin dalam fluktuasi harga saham maupun volume transaksi. Fluktuasi harga saham bisa dihitung memakai abnormal return yang terjadi sekitar periode fenomena (Hidayah, 2019). Pergerakan harga saham juga dipengaruhi oleh aktivitas perdagangan saham. Semakin rendah volume perdagangan saham, harga saham akan menurun juga, begitupun sebaliknya (Triono et al., 2021). Menurut Arfani et al. (2021), adanya pandemi Covid-19 sangat memengaruhi aktivitas di pasar modal Indonesia karena investor cenderung mengharapkan resiko yang terkecil saat melaksanakan investasi hingga dengan terdapat pandemi Covid-19 membuat investor cenderung berhati-hati sebelum mengambil keputusan investasi, sehingga diduga akan ada perbedaan AAR, CAR, dan TVA antara sebelum dan setelah adanya pandemi Covid-19. Peristiwa ini memunculkan urgensi studi lebih lanjut untuk mengetahui pengumuman kasus pasien Covid-19 pertama di Indonesia ini apakah memberikan informasi bagi para investor serta untuk mengetahui sejauh mana kecepatan pasar merespon atas berita yang ada hingga perlu adanya studi komparatif untuk membandingkan keadaan sebelum dan setelah adanya pandemi Covid-19 di Indonesia (Rori et al., 2021).

Tujuan dari riset ini ialah mengkaji apakah ada beda yang signifikan average abnormal return, cumulative abnormal return, dan trading volume activity sektor mining sebelum dan sesudah pemberitaan konfirmasi pasien Covid-19 pertama di Indonesia.

\section{KAJIAN PUSTAKA DAN PENGEMBANGAN HIPOTESIS}

\section{Teori Sinyal}

Menurut Ramandani et al. (2019), sinyal merupakan isyarat yang bersumber dari pihak emiten untuk pihak luar yang bertujuan untuk mengubah penilaian investor terhadap perusahaan. Ada beberapa sinyal yang dapat diamati secara langsung, serta ada pula yang perlu analisis dan pemahaman mendalam untuk mengetahui informasi yang terkandung. Harga saham dan total saham yang diperjual belikan merupakan salah satu sinyal tentang kondisi terkini emiten untuk pihak eksternal yang termuat dalam laporan keuangan yang diterbitkan oleh perusahaan. Laporan keuangan yang diterbitkan perusahaan sangat berguna sebagai sinyal untuk investor dalam penyusunan portofolio investasi dengan penyusunan preferensi risiko uang diharapkan pula (Raya, 2020). Maknanya, sinyal yang diberikan mesti memiliki dampak informasi (information content) sebagai tujuan mengubah penilaian pihak eksternal terhadap perusahaan. Menurut Hafidz (2020), teori sinyal berasumsi bahwa investor bertindak sesuai dengan informasi yang diperoleh.

\section{Return Saham}

Menurut Hartono (2017:283), return adalah pengembalian atau output yang didapat dari sebuah kegiatan investasi. Return bisa berbentuk return realisasi (actual return) yang merupakan return yang sudah terlaksana, atau dapat berupa return ekspetasi (expected return).

\section{Abnormal Return}

Sambuari et al. (2015) menyatakan bahwa abnormal return atau return realisasi adalah keuntungan atau selisih dari actual return kepada return yang diekspetasikan (expected return). Terjadinya abnormal return mengindikasikan bahwa sebuah fenomena mempunyai kandungan informasi sehingga mengakibatkan pasar bereaksi (Hafidz, 2020). Setelah itu cumulative abnormal return (CAR) periode $\mathrm{t}-7$ dan $\mathrm{t}+7$ dihitung untuk memperbandingkan kenaikan atau penurunan sekuritas yang diteliti. 
Lailatul Akhadiyah \& Yuyun Isbanah. Analisis Komparatif Abnormal Return dan Trading Volume Activity Emiten Sektor Mining Berdasarkan Pengumuman Kasus Pasien Covid-19 Pertama di Indonesia

$\mathrm{RTN}_{\mathrm{i}, \mathrm{t}}=\mathrm{R}_{\mathrm{i}, \mathrm{t}}-\mathrm{E}\left[\mathrm{R}_{\mathrm{i}, \mathrm{t}}\right]$

\section{Trading Volume Activity}

Menurut Suryawijaya \& Setiawan (1998), trading volume activity ialah instrumen yang dipakai guna menilai respon pasar modal kepada sebuah peristiwa yang mengandung berita dengan menggunakan tolok ukur aktivitas volume perdagangan saham pada pasar modal.

$\mathrm{TVA}=\frac{\sum \text { saham perusahaan }_{-\mathrm{i}} \text { yang ditransaksikan pada hari ke }}{-\mathrm{t}}$

\section{Hubungan antar Variabel}

Zubaidah (2016) menyatakan bahwa return saham merupakan perolehan dari kegiatan investasi. Abnormal return ialah variabel yang dipakai pada riset studi peristiwa ini. Terdapat abnormal return mengindikasikan jika suatu fenomena mempunyai muatan berita tertentu sehingga memicu terjadinya reaksi di pasar modal, oleh sebab itu Abnormal return relevan ketika digunakan. Menurut Aditha \& Adiputra (2020), respon pasar kepada sebuah berita bisa dicerminkan melalui timbulnya return yang tidak normal (Abnormal return). Abnormal return jadi satu di antara parameter yang mampu mencerminkan bahwa sebuah fenomena bermuatan berita bagi para investor, dan sebaliknya abnormal return tidak terjadi apabila siatu peristiwa yang terjadi tidak mengandung informasi bagi para investor. Menurut Hafidz (2020), terdapatnya perbedaan rata-rata abnormal return mencerminkan pasar bereaksi terhadap suatu peristiwa karena memiliki kandungan informasi sehingga signaling theory mengindikasikan bahwa informasi yang terkandung dapat ditelaah dengan baik oleh investor. Daisy \& Debakshi (2020) menyatakan jika Covid-19 berdampak secara signifikan kepada return saham pasar modal India. Adanya ketidaksamaan abnormal return yang signifikan before and after adanya kasus pasien Covid-19 awal muncul di Indonesia ditunjukkan pada penelitian Febriyanti (2020) yang menunjukkan signifikansi perbedaan abnormal return pada before and after pemberitaan Covid-19 awal muncul. Hasil ini memberikan sinyal bahwa investor memperoleh bad news sehingga menyebabkan harga saham LQ-45 cenderung turun. Penelitian Wicaksono \& Adyaksana (2020) menyatakan terdapat pengaruh signifikan negatif Covid-19 kepada return saham sektor perbankan. AlAwadhi et al (2020) juga menyatakan Covid-19 berpengaruh signifikan negatif terhadap return saham. Tetapi, riset yang dilaksanakan oleh Sambuari et al. (2020) mengatakan jika tidak ada beda di antara abnormal return sebelum dan setelah adanya pemberitaan pasien awal muncul kasus Covid-19 di Indonesia.

H1: Ada perbedaan abnormal return antara sebelum dan setelah diumumkannya kasus pasien Covid19 pertama di Indonesia sektor mining.

Menurut Hafidz (2020), ada berbeda sebelum dan setelah RUU KPK 2019 disahkan yang diakibatkan oleh hasil CAR yang cukup tinggi pada salah satu periode sebelum pengesahan sehingga memengaruhi CAR secara kumulatif. Sejalan dengan Hindayani (2020), terdapat beda yang signifikan negatif CAR pada bidang hotel, pariwisata dan restoran, tetapi tidak ditemukan beda signifikan untuk subsektor farmation, telecommunication, dan food and beverage sebelum dan sesudah adanya Covid-19. Sedangkan Wibawa \& Suryantini (2019) menyatakan tidak ada beda CAR sebelum dan sesudah pemberitaan right issue yang menyatakan jika fenomena ini telah terjadi kebocoran informasi yang artinya informasi tentang right issue tersebut sebelumnya telah diketahui oleh investor sehingga tidak terjadi reaksi pasar. Penelitian Arfani et al. (2021) menyatakan tidak ada perbedaan CAR sebelum dan sesudah ada Covid-19 dikarenakan pasar sejak munculnya Covid-19 tahun 2019 sudah berjaga-jaga sehingga pada saat pandemi diumumkan di Indonesia, pasar tidak terlalu bereaksi.

H2: Ada perbedaan cumulative abnormal return antara sebelum dan setelah diumumkannya kasus pasien Covid-19 pertama di Indonesia sektor mining.

Wenno (2020) menyatakan bahwa trading volume activity ialah total saham yang diperjual belikan per kurun tertentu. Besarnya trading volume activity menjelaskan minat investor terhadap saham. Nilai trading volume activity yang besar belum pasti mencerminkan harga saham yang besar pula. Menurut 
Aditha \& Adiputra (2020), adanya sinyal berita yang termuat pada sebuah kejadian dapat memicu reaksi pasar melalui volume perdagangan saham,bisa bertambah ataupun berkurang mengikuti sinyal yang terkandung pada berita itu. Chiah \& Zhong (2020) menyatakan trading volume activity cenderung naik setelah adanya pandemi Covid-19. Menurut Hafidz (2020), jika peningkatan trading volume activity dikarenakan peningkatan permintaan, informasi yang terkandung dalam suatu peristiwa merupakan kabar baik (good news), dan jika peningkatan trading volume activity disebabkan tingginya penjualan, informasi yang terkandung dalam suatu peristiwa merupakan kabar buruk (bad news). Beberapa penelitian terdahulu menggunakan trading volume activity sebagai variabel yang dapat merefleksikan kondisi pasar seperti riset yang dilaksanakan oleh Dewi \& Masithoh (2020) yang mengatakan jika tidak ada beda trading volume activity sebelum dan sesudah kejadian pemberitaan kasus awal mula pasien Covid-19 di Indonesia. Hal berbeda ditunjukkan oleh Nurmasari (2020) yang mengatakan jika ada beda trading volume activity sebelum dan setelah kejadian yang menunjukkan pertambahan volume transaksi saham sesudah adanya Covid-19 meskipun di sisi lain harga saham mengalami penurunan.

H3: Ada perbedaan trading volume activity sebelum dan setelah diumumkannya kasus pasien Covid19 pertama di Indonesia sektor mining.

\section{METODE PENELITIAN}

Jenis riset yang dipakai pada studi ini ialah uji komparatif dan studi peristiwa (event study). Riset ini dilakukan guna mendeteksi adanya beda yang signifikan di antara Average Abnormal Return (AAR), cumulative abnormal return (CAR), dan trading volume activity (TVA) sebelum dan setelah adanya pemberitaan fenomena pasien Covid-19 pertama di Indonesia tanggal 2 Maret 2020 sebagai akibat dari pengaruh peristiwa tersebut.

Populasi penelitian ini adalah 50 perusahaan sektor mining dari 5 sektor yang yang tercatat pada bulan februari-maret 2020 di Bursa Efek Indonesia (BEI). Pada riset ini, sampel dipilih dengan teknik nonprobability sampling memakai metode purposive sampling dengan kriteria pengambilan sampel berikut. (1) Emiten sektor mining yang listing di BEI sekitar periode peristiwa. (2) Saham yang diperdagangkan masih aktif pada sekitar periode peristiwa. (3) Emiten sampel tidak melakukan corporate action saat periode peristiwa baik dalam bentuk merger, akuisisi, stock split, buy back, delisting, reserve stock split, maupun menerbitkan right issue.

Setelah pemilihan sampel, diperoleh 41 perusahaan sektor mining yang terdaftar di Bursa Efek Indonesia (BEI) sebagai sampel riset. Teknik penghimpunan data yang dipakai di riset ini ialah Teknik dokumentasi. Teknik analisis data riset ini dengan teknik analisis Wilcoxon Signed Rank Test dengan bantuan IBM SPSS 25 guna analisa beda abnormal return dan trading volume activity sebelum dan sesudah pengumuman peristiwa awal pasien Covid-19 di Indonesia.

\section{HASIL DAN PEMBAHASAN}

\section{Hasil Uji Statistik Desktiptif}

Tabel 1 mencerminkan hasil uji statistik deskriptif sampel penelitian yang berjumlah 41 perusahaan sektor mining yang terdaftar di Bursa Efek Indonesia (BEI) selama 7 hari sebelum dan setelah peristiwa yang memperoleh nilai minimum, maksimum, mean, dan standar deviasi untuk AAR, CAR, dan TVA.

\section{Hasil Uji Normalitas}

Uji normalitas dilakukan setelah melaksanakan uji statistik deskriptif, tujuan ada pengujian normalitas adalah guna menyimpulkan data yang sudah diolah peneliti berdistribusi normal atau tidak berdistribusi normal. Uji normalitas memakai Kolmogorov-smirnov memperoleh hasil Asymp. Sig (2-tailed) dari AAR, CAR, dan TVA untuk data sebelum dan sesudah pemberitaan fenomena awal pasien Covid-19 di Indonesia masing-masing di bawah 0,05 yang maknanya data tidak tersebar normal. 
Lailatul Akhadiyah \& Yuyun Isbanah. Analisis Komparatif Abnormal Return dan Trading Volume Activity Emiten Sektor Mining Berdasarkan Pengumuman Kasus Pasien Covid-19 Pertama di Indonesia

Tabel 1.

UJI STATISTIK DEKSRIPTIF

\begin{tabular}{cccc}
\hline \multirow{2}{*}{ Variabel } & \multirow{2}{*}{ Statistik Deskriptif } & \multicolumn{2}{c}{ Periode } \\
& Minimun & $-0,0433$ & $-0,0270$ \\
\multirow{4}{*}{ AAR } & Maximum & 0,2008 & 0,3011 \\
& Mean & 0,0002 & 0,0042 \\
& Std. Deviation & 0,0157 & 0,0117 \\
& Minimun & $-0,3031$ & $-0,1892$ \\
CAR & Maximum & 0,1405 & 0,2107 \\
& Mean & 0,0017 & 0,0297 \\
& Std. Deviation & 0,1097 & 0,0816 \\
TVA & Minimun & 0,0000 & 0,0000 \\
& Maximum & 0,0738 & 0,0642 \\
& Mean & 0,0058 & 0,0047 \\
& Std. Deviation & 0,0138 & 0,0118 \\
\hline
\end{tabular}

Sumber: SPSS (2021, data diolah)

Tabel 2.

UJI STATISTIK DEKSRIPTIF

\begin{tabular}{cccc}
\hline Variabel & Periode & Asymp Sig. & Keterangan \\
\hline \multirow{2}{*}{ AAR } & $\mathrm{t}-7$ & 0,003 & Berdistribusi Tidak Normal \\
& $\mathrm{t}+7$ & 0,001 & Berdistribusi Tidak Normal \\
\multirow{2}{*}{ CAR } & $\mathrm{t}-7$ & 0,003 & Berdistribusi Tidak Normal \\
& $\mathrm{t}+7$ & 0,001 & Berdistribusi Tidak Normal \\
\multirow{2}{*}{ TVA } & $\mathrm{t}-7$ & 0,000 & Berdistribusi Tidak Normal \\
& $\mathrm{t}+7$ & 0,000 & Berdistribusi Tidak Normal \\
\hline
\end{tabular}

Sumber: SPSS (2021, data diolah)

\section{Hasil Uji Hipotesis}

Tabel 3.

UJI STATISTIK DEKSRIPTIF

\begin{tabular}{cccc}
\hline Variabel & Periode & Asymp Sig. & Keterangan \\
\hline AAR & $\mathrm{t}+7 ; \mathrm{t}-7$ & 0,197 & Tidak signifikan \\
CAR & $\mathrm{t}+7 ; \mathrm{t}-7$ & 0,197 & Tidak signifikan \\
TVA & $\mathrm{t}+7 ; \mathrm{t}-7$ & 0,336 & Tidak signifikan \\
\hline Sumber: SPSS (2021, data diolah) &
\end{tabular}

Wilcoxon Signed Rank Test dilaksanakan sebab data yang diolah tidak memenuhi asumsi normalitas. Pengujian hipotesis ditujukan guna meninjau apakah ada perbedaan yang signifikan antara AAR, Car dan TVA sebelum dan setelah peristiwa. Setelah dilaksankan pengujian Wilcoxon Signed Rank Test dengan hasil signifikansi AAR, CAR, dan TVA di atas 0,05 sehingga $\mathrm{H} 1, \mathrm{H} 2$, dan $\mathrm{H} 3$ tidak dapat dibuktikan.

\section{Perbedaan AAR antara Sebelum dan Setelah Pengumuman Pertama Kasus Pasien Covid-19 di Indonesia}

Setelah melakukan uji hipotesis, tidak ditemukan adanya perbedaan yang signifikan average abnormal return (AAR) sebelum dan sesudah pemberitaan kasus awal pasien Covid-19 di Indonesia. Hal ini berarti peristiwa pemberitaan kasus awal pasien Covid-19 di Indonesia tidak mengandung informasi apapun bagi investor di sektor mining sehingga pasar modal untuk sektor mining tidak bereaksi terhadap peristiwa ini. Abnormal return ialah selisih dari actual return kepada expected return. Adanya abnormal return mengindikasikan bahwa pasar bereaksi kepada sebuah fenomena yang mempunyai muatan berita yang dapat mengubah ekspetasi investor terhadap nilai perusahaan, bentuk reaksi dari adanya peristiwa tersebut berupa kenaikan atau penurunan harga saham (Hartono, 2017:644). Hasil riset 
ini sesuai dengan output riset Sambuari et al. (2020) yang mengatakan jika tidak ada perbedaan Abnormal Return sebelum dan setelah kejadian pemberitaan kasus pasien pertama Covid-19 di Indonesia. Karena wabah ini mengjangkit negara-negara di seluruh dunia serta Indonesia bukan negara pertama yang terjangkit wabah Covid-19, sehingga investor cenderung berspekulasi bahwa mereka tidak akan bisa menginvestasikan uangnya ke negara lain karena negara lain juga terkena wabah Covid19. Sehingga, investor cenderung melakukan wait and see setelah wabah, sehingga investor cenderung mengamati kondisi lingkungan dan tidak tergesa-gesa saat mengambil putusan, hingga fenomena ini tidak berdampak ke abnormal return bagi investor. Penelitian Randina \& Fachrizal (2016) juga menunjukkan jika tidak ada beda AAR sebelum dan sesudah perolehan Indonesia Suistanability Reporting Award (ISRA). Namun hal yang berbeda dimuat dalam penelitian Khoiriah et al. (2020) yang mengatakan ada beda yang signifikan AAR sebelum dan sesudah adanya Covid-19. Hal yang serupa pun dinyatakan oleh Febriyanti (2020) yang mengasumsikan tidak ada beda yang signifikan antara abnormal return sebelum dan sesudah adanya pandemi Covid-19.

Hasil penelitian ini tidak sesuai dengan teori sinyal bahwa pemberitaan fenomena awal pasien Covid19 di Indonesia memengaruhi abnormal return. Harapan penelitian ini dapat jadi sebuah riset yang menyatakan tidak adanya perbedaan AAR antara sebelum dan sesudah pemberitaan kasus pasien Covid19 awal di Indonesia. Penelitian ini dapat menjadi acuan untuk para investor sebelum membuat kebijakan investasi serta bisa dijadikan peluang untuk investor melakukan pembelian saham dengan harapan harga saham sektor mining suatu saat akan naik jika pandemi sudah berlalu.

\section{Perbedaan Cummulative Abnormal Return antara Sebelum dan Setelah Pengumuman Kasus Pasien Covid-19 Pertama di Indonesia}

Output uji hipotesis untuk variabel Cummulative abnormal return (CAR) dengan memakai Wilcoxon signed ranked test menunjukkan hasil tidak ada beda yang signifikan antara Cummulativ abnormal return (CAR) sebelum dan setelah adanya pengumuman kasus pasien Covid-19 pertama di Indonesia. Hal ini mengartikan bahwa penelitian ini menolak hipotesis 2 yang menyatakan jika ada beda CAR sebelum dan setelah berita masalah pasien Covid-19 pertama di Indonesia. Hasil penelitian ini didukung dengan adanya nilai CAR positif yang cukup besar setelah adanya pandemi Covid-19 yaitu pada $t+4$ dan $t+3$. Hal ini sebanding dengan penelitian Raya (2020) yang mengatakan tidak ada beda yang signifikan antara CAR sebelum dan setelah peristiwa. Hal ini mengartikan bahwa investor memperoleh signaling theory informasi positif yang lebih besar dengan adanya pandemi ini (Susanti, 2015). Penelitian Hindayani (2020), juga mengatakan jika tidak ada beda yang signifikan diantara CAR sebelum dan sesudah pemberitaan terkonfirmasi Covid-19 di Indonesia untuk bidang farmasi, telekomunikasi, juga makanan dan minuman. Bahkan, CAR sektor ini cenderung meningkat karena sektor-sektor ini merupakan sektor yang dibutuhkan data pandemi covid-19. Namun, Hindayani (2020) juga menyatakan ada beda yang signifikan CAR pada emiten sektor hotel, pariwisata, dan restoran sesudah adanya pandemi Covid-19. Sektor ini terdampak kebijakan social distancing sangat merugikan sektor ini sehingga return yang diperoleh perusahaan pada sektor ini mengalami penurunan. Riset ini menunjukkan tidak terdapat beda yang signifikan antara Cummulative abnormal return sebelum dan sesudah pemberitaan pasien Covid-19 pertama di Indonesia karena jika ditinjau dari abnormal return sebelum dan sesudah fenomena tidak menunjukkan beda yang signifikan. Selain itu, setelah adanya peristiwa Covid-19 di Indonesia nilai AR pada $t+4, t+3$, dan $t+7$, nominal AR menjadi cukup besar sehingga memiliki pengaruh yang cukup besar terhadap tingginya CAR setelah peristiwa.

Seperti yang sudah disampaikan sebelumnya, signaling theory tidak terbukti dalam penelitian ini. Padahal, kejadian yang bermuatan berita akan memberikan sinyal terhadap investor sehingga pasar modal akan bereaksi. Penelitian ini sejalan teori efisiensi pasar karena semakin sedikit informasi yang diperoleh investor dari emiten mengenai return saham, investor semakin tidak tertarik dengan saham yang mereka jual. Investor diharapkan tetap berhati-hati dalam mengambil keputusan investasi karena tidak semua peristiwa yang terjadi mengandung informasi sehingga investor tetap dapat memaksimalkan keuntungan ditengah kondisi yang tidak pasti. 
Lailatul Akhadiyah \& Yuyun Isbanah. Analisis Komparatif Abnormal Return dan Trading Volume Activity Emiten Sektor Mining Berdasarkan Pengumuman Kasus Pasien Covid-19 Pertama di Indonesia

\section{Perbedaan Trading Volume Activity Sebelum dan Setelah Pengumuman Pertama Kasus Pasien Covid-19 di Indonesia}

Hasil pengujian variabel trading volume activity emiten sektor mining sebelum dan setelah adanya berita masalah pasien Covid-19 pertama di Indonesia dengan menggunakan uji Wilcoxon sign rank test menunjukkan tidak ada beda yang signifikan. Hal ini mengasumsikan jika $\mathrm{H} 3$ yang menyatakan ada beda yang signifikan antara trading volume activity sebelum dan setelah berita masalah pasien Covid19 pertama di Indonesia ditolak. Hasil riset ini sama halnya dengan penelitian Hafidz (2020) yang mengasumsikan tidak ada beda yang signifikan antara TVA sebelum dan setelah kejadian yang mengindikasikan bahwa informasi yang diterima oleh investor tidak memiliki muatan berita sehingga investor cenderung mengambil sikap wait and see. Demikian pula penelitian Rori et al. (2021) yang mengasumsikan tidak terdapat beda yang sigifikan baik secara parsial maupun secara gabungan hal ini bisa terjadi karena strategi tiap investor berbeda. Para investor menggunakan teknik wait and see atau menunggu momen yan pas guna masuk maupun keluar dari pasar, atau bisa juga dikarenakan para investor percaya pada nilai saham jangka panjang yang dimiliki suatu perusahaan dibanding dengan informasi jangka pendek yang diterima oleh investor. Berbeda dengan hasil penelitian ini, penelitian Chiah \& Zhong (2020) menyatakan ada perbedaan TVA sebelum dan setelah adanya Covid-19 yang cenderung mengalami peningkatan, seperti halnya penelitian Sambuari et al. (2020) yang menyatakan ada beda antara TVA sebelum dan setelah peristiwa berita masalah Covid-19 pertama yang menunjukkan peningkatan frekuensi penjualan saham. Hal ini dikarenakan adanya dampak dari kabar buruk (bad news) yang diterima investor sehingga investor cenderung melakukan panic selling karena investor menganggap bahwa menjual saham merupakan satu langkah untuk mengamankan asset yang digunakan untuk investasi di saham kemudian dialihkan ke investasi emas sehingga mengakibatkan kenaikan harga emas pada beberapa minggu semenjak pemberitaan masalah Covid-19 awal di Indonesia. Selain itu, penelitian Siswantoro (2020) menyatakan bahwa ada beda signifikan antara volume saham yang dijualbelikan sesudah pengumuman masalah awal Covid-19 yang menunjukkan adanya penurunan perdagangan saham.

Implikasi teoritis dari riset ini tidak sesuai dari teori sinyal (signaling theory) bahwa pemberitaan masalah pasien Covid-19 awal di Indonesia disinyalir akan memengaruhi TVA karena tidak terdapat beda antara sebelum dan setelahadanya peristiwa. Investor dianjurkan untuk lebih selektif dalam mengambil keputusan investasi serta investor dianjurkan untuk wait and see karena investor kemungkinan tidak dapat menyelamatkan dananya untuk berinvestasi di pasar modal negara lain. Selain itu, investor dianjurkan untuk mencari informasi dari sumber lainnya dikarenakan keterbatasan informasi yang diberikan oleh emiten sektor mining sehingga menyebabkan kepercayaan investor terhadap sektor mining sedikit rendah karena pada dasarnya kepercayaan dan pilihan investasi dalam konteks pemilihan portofolio. Investor cenderung berekspetasi resiko yang diambil kecil (Darmayanti et al., 2021).

\section{KESIMPULAN}

Hasil penelitian menunjukkan tidak ada beda AAR, CAR, dan TVA pada emiten sektor mining sebelum dan setelah pemberitaan masalah pasien Covid-19 pertama di Indonesia. Hal ini karena Indonesia bukan negara pertama yang mengumumkan kasus virus Corona. Artinya, informasi yang diterima oleh investor di pasar modal Indonesia cenderung sama dengan di pasar luar negeri, sehingga para investor tidak dapat mengamankan dana mereka ke negara lain, karena negara lain juga mengalami hal yang serupa. Adanya pandemi Covid-19 menyebabkan para penanam modal cenderung mengambil sikap wait and see karena investor tidak ingin tergesa-gesa dalam mengambil keputusan sehingga peristiwa ini tidak menimbulkan reaksi di pasar modal. Meskipun tidak didapatkan hasil yang signifikan dari penelitian ini, emiten sektor mining diharap mampu untuk meningkatkan performa saat pandemi sehingga memunculkan peluang peningkatan pendapatan dan menarik minat investor untuk membeli saham dari sektor mining. Investor diharap mengambil keputusan investasi dengan cermat di masa pandemi dengan mempertimbangkan tidak hanya efek jangka pendek, tetapi jangka panjang sehingga keputusan investasi yang diambil akan mendatangkan keuntungan. Keterbatasan dalam riset ini ialah event windows yang cukup pendek dengan rentang waktu $\mathrm{H}-7$ hingga $\mathrm{H}+7$ saja. Penelitian selanjutnya diharapkan mengubah event windows dengan mempertimbangkan kemungkinan efek pengganggu 
(confounding effect) serta mempertimbangkan Covid-19 ini merupakan pandemi jangka panjang yang bahkan sampai saat ini masih berlangsung. Selain itu, penelitian selanjutnya dapat memilih sampel yang berbeda sehingga menambah wawasan di emiten sektor lainnya serta disarankan untuk mengambil sampel pasar modal di negara-negara lain yang juga terkonfirmasi adanya kasus pasien Covid-19 mengingat pandemi Covid-19 ini melanda seluruh negara-negara di dunia.

\section{DAFTAR PUSTAKA}

Aditha, K. K., \& Adiputra, I. M. P. (2020). Analisis Perbedaan Abnormal Return , Trading Volume Activity, Dan Security Return Variability Pada Perusahaan LQ 45 Pra Dan Pasca Pengumuman Kabinet Indonesia Maju Periode 2019-2024. JIMAT (Jurnal Ilmiah Mahasiswa Akuntansi) Universitas Pendidikan Ganesha, 11(2), 299-306.

Ahyaruddin, M., Widiarsih, D., \& Winarso, D. (2017). Pengaruh Psikologi Investor Terhadap Volume Perdagangan Saham (Studi Empiris Pada Indeks Saham LQ-45 Yang Terdaftar di BEI) The Effect Of Investor Psychology On Trading Volume (Empirical Study on Index LQ45 Listed in Indonesia Stock Exchange). Jurnal Akutansi Dan Ekonomika, 7(2), 121-130.

Al-Awadhi, A. M., Alsaifi, K., Al-Awadhi, A., \& Alhammadi, S. (2020). Death and contagious infectious diseases: Impact of the COVID-19 virus on stock market returns. Journal of Behavioral and Experimental Finance, 27, 1-13. https://doi.org/10.1016/j.jbef.2020.100326

Alexander, A., \& Kadafi, M. A. (2018). Analisis abnormal return dan trading volume activity sebelum dan sesudah stock split pada perusahaan yang terdaftar di bursa efek indonesia. Jurnal Manajemen, 10(1), 1-6. https://doi.org/10.29264/jmmn.v10i1.3803

Annisa Susanti. (2015). Widodo-Jusuf Kalla dalam Pilpres 2014 Terhadap Abnormal Return dan Trading Volume Activity Pada Kelompok Saham Indeks Lq45. Jurnal Ekonomia, 11 (2), 1-15.

Arfani, F. S. (2021). Analisis Reaksi Pasar Modal Sebelum dan Saat Peristiwa Pandemi Covid-19 ( Event Study pada Perusahaan yang terdaftar LQ-45 di Bursa Efek Indonesia Tahun 2020 ). Jurnal Akuntansi dan Keuangan, 5(3). 210-222.

Bimantara, R. A., Siswanto, E., \& Soesetio, Y. (2019). Pengumuman Perhitungan Baru Indeks LQ45 dan IDX30: Apakah Ada Reaksi pada Pasar Modal Indonesia? Esensi: Jurnal Bisnis Dan Manajemen, 9(1), 27-40. https://doi.org/10.15408/ess.v9i1.10642

Chiah, M., \& Zhong, A. (2020). Trading from home: The impact of COVID-19 on trading volume around the world. Finance Research Letters, 37, 1-7. https://doi.org/10.1016/j.frl.2020.101784

Daisy, B., \& Debakshi, B. (n.d.). The outbreak of COVID-19 pandemic and Its Impact on Stock Market Volatility: Evidence from a worst-affected economy. Finance Research Letters, 35, 1-23. https://doi.org/10.21203/rs.3.rs-57471/v1.

Darmayanti, N., Mildawati, T., \& Dwi Susilowati, F. (2021). Dampak Covid-19 Terhadap Perubahan Harga Dan Return Saham. EKUITAS (Jurnal Ekonomi Dan Keuangan), 4(4), 462-480. https://doi.org/10.24034/j25485024.y2020.v4.i4.4624.

Dewi, C. K., \& Masithoh, R. (2020). JKSE and Trading Activities Before After Covid-19. Journal of Accounting and Business Management, 4(1), 1-6.

Febriyanti, G. A. (2020). Dampak pandemi Covid-19 terhadap harga saham dan aktivitas volume perdagangan (Studi kasus saham LQ-45 di Bursa Efek Indonesia). Indonesia Accounting Journal. 2(2), 87-91. http://doi.org/10.32400/iaj.30579. 
Lailatul Akhadiyah \& Yuyun Isbanah. Analisis Komparatif Abnormal Return dan Trading Volume Activity Emiten Sektor Mining Berdasarkan Pengumuman Kasus Pasien Covid-19 Pertama di Indonesia

Hafidz, M. F. (2020). Analisis Komparatif Abnormal Return dan Trading Volume Activity Berdasarkan Political Event ( Event Study Pada Pengesahan RUU KPK 2019. Jurnal Ilmu Manajemen, 8(3), 829-838.

Hartono, J. (2017). Teori Portofolio dan Analisis Investas (Kesebelas)i. Yogyakarta: BPFE.

Hidayah, M. K. (2019). Perbedaan Abnormal Return dan Trading Volume Activity Sebelum, Saat dan Sesudah Asian Games Jakarta-Palembang 2018 (Studi Kasus Pada Indeks Liquid 45). Journal of Chemical Information and Modeling, 53(9), 1689-1699.

Hidayati, N., Maslichah, \& Junaidi. (2017). Reaksi Abnormal Dan Trading Volume Activity Terhadap Ramadhan Effect (Studi Pada Perusahaan Food And Beverages Yang Terdaftar Di Bursa Efek Indonesia Periode 2015-2017). Jurnal Ilmiah Riset Akuntansi,7(3), 13-25.

Hindayani, N. (2020). Analisis Reaksi Pasar Saham Atas Peristiwa Covid-19 di Indonesia. JIMEA ( Jurnal Ilmiah Manajemen, Ekonomi dan Akuntansi) 4(3), 1645-1661.

Idxchannel.com. (2020). Pergerakan IHSG Awal Maret 2020. Retrieved January 02 2021, from https://www.idxchannel.com/infografis/pergerakan-ihsg-awal-maret-2020

Indonesia, K. K. R. (2020). Kementerian Kesehatan Republik Indonesia. Retrieved January 10, 2021,from https://www.kemkes.go.id/article/view/20030400008/FAQ-Coronavirus.html

Cnnindonesia.com. (2020). Jokowi Umumkan Dua WNI Positif Corona di Indonesia. Retrieved January 2, 2021, from https://www.cnnindonesia.com/nasional/20200302111534-20-479660/jokowiumumkan-dua-wni-positif-corona-di-indonesia

Kasmir. (2014). Bank dan Lembaga Keuangan Lainnya Edisi Revisi. Jakarta: Raja Grafindo Persada.

Khoiriah, M., Amin, M., \& Kartikasari, A. F. (2020). Pengaruh Sebelum Dan Saat Adanya Pandemi Covid-19 Terhadap Saham Lq-45 Di Bursa Efek Indonesia Tahun 2020. E-Jra, 09(02), 47-57.

Kompas.com. (2020). Menilik Peluang Cuan Investasi Saham di Tengah Pandemi. Retrieved January 10, 2021, from https://money.kompas.com/read/2020/05/12/114000826/menilik-peluang-cuaninvestasi-saham-di-tengah-pandemi

Liu, H., Manzoor, A., Wang, C., Zhang, L., \& Manzoor, Z. (2020). The COVID-19 outbreak and affected countries stock markets response. International Journal of Environmental Research and Public Health, 17(8), 1-19. https://doi.org/10.3390/ijerph17082800

Luhur, S. (2010). Reaksi PAsar Modal Indonesia Seputar Pemilihan Umum 8 Juli 2009 pada Saham LQ-45. Jurnal Keuangan Dan Perbankan, 14(2), 249-262.

Mahardhika, L. A. (2020). Dampak Virus Corona, Jual Panik Warnai Pergerakan IHSG. Retrieved January 2, 2021, from https://market.bisnis.com/read/20200302/7/1207932/dampak-viruscorona-jual-panik-warnai-pergerakan-ihsg

Nurmasari, I. (2020). Dampak Covid-19 Terhadap Perubahan Harga Saham dan Volume Transaksi (Studi Kasus Pada PT. Ramayana Lestari Sentosa, Tbk.). Jurnal SEKURITAS (Saham, Ekonomi, Keuangan Dan Investasi), 3(3), 230-236. https://doi.org/10.32493/skt.v3i3.5022.

Ramandani, E. K., Ari, A. T., \& Riawan. (2019). Pengaruh Peristiwa Jatuhnya Pesawat Lion Air Terhadap Abnormal Return Dan Trading Volume Activity. Jurnal Ekonomi, Manajemen dan Akuntansi, 3(2), 72-86. https://doi.org/10.2207/jjws.88.427 
Randina, T. M. M., \& Fachrizal. (2016). Analisis Perbandingan Kinerja Keuangan, Abnormal Return Dan Volume Perdagangan Saham Antara Periode Sebelum Dan Sesudah Meraih Indonesia. Jurnal Ilmiah Mahasiswa Ekonomi Akuntansi (JIMEKA), 1(2), 71-83.

Raya, C. J. (2020). Analisis Perbedaan Abnormal Return dan Cumulative Abnormal Return Emiten Sektor Keuangan Sekitar Pemilu 17 April 2019. Jurnal Ilmu Manajemen, 8(3), 852-863.

Rori, A., Mangantar, M., \& Maramis, J. B. (2021). Reaksi Pasar Modal Terhadap Pengumuman Pembatasan Sosial Berskala Besar (PSBB) Akibat Covid-19 pada Industri Telekomunikasi di BEI. Jurnal EMBA, 9(1), 851-858.

Sambuari, I. B., Saerang, I. S., \& Maramis, J. B. (2015). Reaksi Pasar Modal Terhadap Peristiwa Virus Corona (Covid-19) Pada Perusahaan Makanan Dan Minuman Yang Terdaftar Di Bursa Efek Indonesia. Jurnal Ilmiah Manajemen Bisnis Dan Inovasi Universitas Sam Ratulangi (Jmbi Unsrat), 7(9), 27-44.

Sambuari, I. B., Saerang, I. S., \& Maramis, J. B. (2020). Reaksi Pasar Modal Terhadap Peristiwa Virus Corona (Covid-19) Pada Perusahaan Makanan Dan Minuman Yang Terdaftar Di Bursa Efek Indonesia. Jurnal Ilmiah Manajemen Bisnis dan Inovasi Universitas Sam Ratulangi, 7(3),407415.

Sindonews.com. (2020). Sektor Tambang Tetap Tangguh di Tengah Badai Pandemi. Retrieved January 2, 2021, from https://makassar.sindonews.com/read/106306/712/sektor-tambang-tetap-tangguhdi-tengah-badai-pandemi-1595167648

Siswantoro, S. (2020). Efek Diumumkannya Kasus Pertama Covid-19 Terhadap Harga Saham dan Total Saham yang Diperdagangkan ( The Effect of The First Covid-19 Case Announcement on Stock Prices and Stock Trading Totals ). Jurnal Akuntansi, Keuangan, Dan Manajemen, 1(3), 227-238.

Suryawijaya, M. A., \& Setiawan, F. A. (1998). Reaksi Pasar Modal Indonesia Terhadap Peristiwa Politik Dalam Negeri (Event Study pada Peristiwa 27 Juli 1996). Kelola 7(18), 137-153.

Tandelilin, E. (2010). Portofolio dan Investasi : Teori dan Aplikasi. Yogyakarta: Kanisius.

Triono, B., Hendrayanti, S., Fauziyanti, W., \& Estuti, E. P. (2021). Comparative Analysis of Trading Volume Activity During Covid-19. Jurnal Stie Semarang, 13(1), 39-50.

Wenno, M. (2020). Dampak Covid-19 Terhadap Perubahan Harga Saham dan Volume Transaksi (Studi Kasus pada PT. Bank Mandiri.Tbk). Jurnal SOSOQ 4(2), 84-91.

Wibawa, I. G. A. S. (2019). Perbedaan Abnormal Return dan Trading Volume Activity Sebelum dan Sesudah Pengumuman Right Issue di BEI. E- Journal Manajemen, 8(4), 2381-2408. https://doi.org/10.24843/EJMUNUD.2019.v8.i4.p18.

Wicaksono, C. A., \& Adyaksana, R. I. (2020). Analisis Reaksi Investor Sebagai Dampak Covid-19 Pada Sektor Perbankan di Indonesia. JIAFE (Jurnal Ilmiah Akuntansi Fakultas Ekonomi), 6(2), 129-138. https://doi.org/10.34204/jiafe.v6i2.2227

Zubaidah, D. D. (2016). Pengaruh Pengumuman Pemberlakuan Larangan Ekspor Mineral dan Batu Bara (Minerba) Mentah Terhadap Reaksi Pasar Saham Sektor Mining. Jurnal Ilmiah Mahasiswa FEB, 4(2), 1-14. 